Włodzisław Duch

PL ISSN 0044 - 1619

Katedra Informatyki Stosowanej

Wydział Fizyki, Astronomii i Informatyki Stosowanej UMK

Laboratorium Neurokognitywne

Interdyscyplinarne Centrum Nowoczesnych Technologii UMK

email:wduch@umk.pl

ORCID: 0000-0001-7882-4729

\title{
Zagadnienie interdyscyplinarności w perspektywie polityki naukowej w Polsce
}

DOI: http://dx.doi.org/10.12775/ZN.2019.012

\section{Czym powinien być, a czym nie jest uniwersytet?}

Czym powinien być, a czym obecnie jest uniwersytet? W większości krajów rozwiniętych to wspólnota akademicka, stwarzająca możliwości rozwoju jej członkom, pracownikom i studentom, organizacja wspierająca ich dążenia do tworzenia wiedzy. Przynależność do uniwersytetu umożliwia wspólne działanie, odkrywanie nowej wiedzy i tworzenie naukowych teorii pozwalających na lepsze zrozumienie świata, budowę urządzeń i rozwój nowych form organizacji, kształtowanie osobowości i kompetencji studentów. Im mniej przepisów krępuje działalność uniwersytetu, tym większe szanse na jego prawidłowe działanie. Trzeba oczywiście oceniać, czy pieniądze przeznaczane na uniwersytet nie są marnowane, czy prowadzone w nim badania są na oczekiwanym poziomie, czy opuszczający go studenci naprawdę czegoś się nauczyli i czy będzie z nich pożytek. To jednak wszystko, co trzeba robić. Im więcej ograniczeń i przepisów, drobiazgowych kontroli, tym mniejsze szanse na twórcze działanie. Uniwersytety biorą udział w maratonie, konkurując ze sobą w kraju, w Europie, w skali globalnej na wiele sposobów. Nie można wymagać wyników, jeśli najpierw skuje się zawodnikowi nogi kajdankami, a potem każe biegać.

Nic dziwnego, że nie mamy w Polsce żadnego uniwersytetu należącego do ligi europejskich uniwersytetów badawczych (LERU). Do niedawna to nie uniwersytet wydawał dyplomy, to nie uniwersytet zatwierdzał doktoraty, habilitacje i profesury, robiły to rady wydziałów. Nowe specjalności rodziły się przez pączkowanie, rozrastanie się tego, co już jest. Jak wiemy, ewolucja odkryła bardziej efektywne rozmnażanie płciowe, krzyżówki genetyczne, a więc interdyscyplinarność. To nie 
uniwersytet organizował kierunki studiów, robiły to wydziały. Na poziomie senatu przyklepywano decyzje wydziałów. Wspólnych inicjatyw pomiędzy wydziałami było niewiele, bo utrudniały to przepisy. W 2001 r. opublikowałem w Sprawach Nauki (12(75), s. 12-13) artykuł „Szufladki w nauce, czyli smutne refleksje z Brukseli”, zawierający gorzkie przemyślenia nad grantami w 5 Programie Ramowym, ocenianymi przeze mnie w obszarze nauk o życiu (life science). Takie pojęcie u nas nie istniało. Prawie wszystkie granty przyznawane w Brukseli były związane z badaniami interdyscyplinarnymi, wymagającymi szerokiej współpracy. Niestety projekty z Polski do takich nie należały. Nie pasowały do tradycyjnych szufladek. Oceniający nasz wydział eksperci kazali nam zdecydować się, czy to prace z fizyki, chemii czy matematyki, bo o innych na naszym wydziale nie mogło być mowy. Wybory członków różnych akademii, prestiżowe nagrody są w rękach ekspertów, którzy doceniają osiągnięcia w swojej dyscyplinie, ale nie w nowo powstających obszarach nauki (emerging fields). Budowanie czegoś od podstaw jest znacznie trudniejsze niż rozwijanie tradycyjnych dyscyplin.

To miało się zmienić, ale „myślenie wydziałami” nie znikło, a dodatkowo dzięki nowej ustawie mamy „myślenie dyscyplinami”. Ponieważ większość uczelni nadal ma strukturę wydziałową, trzeba dopasować się do dyscyplin przypisanych do wydziału. Jeśli mamy psychologa klinicznego na wydziale społeczno-humanistycznym, który testuje nowe formy neurofeedback, wymagające współpracy informatyków i psychiatrów, to która szkoła doktorska przyjmie jego doktoranta? Takie badania będziemy w Polsce uprawiać za 20 lat, kiedy wszędzie będą już mocno zaawansowane. We wrześniu 2019 r. w naszym Laboratorium Neurokognitywnym, jednym z nielicznych naprawdę transdyscyplinarnych laboratoriów, w którym pracują humaniści (psychologowie, filozofowie, filologowie), fizycy, informatycy, automatycy od nauk technicznych, neuronaukowcy, psychologowie kliniczni, udało się obronić doktorat oparty na badaniach behawioralnych z użyciem funkcjonalnego neuroobrazowania (fMRI) i analizach za pomocą nowo powstałych neuronauk sieciowych (network neuroscience). Rozpatrywaliśmy obronę na wydziałach psychologii, biologii, medycyny i w końcu biofizyki, do której badania fMRI też można przypisać. Radzie dyscypliny trzeba było tłumaczyć, że aspekty poruszane w omawianej pracy doktorskiej należą również do obszaru nauk fizycznych. Trudno jednak stworzyć środowisko naukowe wokół jakiejś specjalności, jeśli w różnych ośrodkach jest przypisywana do całkiem innej dyscypliny. Takie myślenie to jedna $\mathrm{z}$ głównych przeszkód zmiany nastawienia $\mathrm{w}$ stosunku do interdyscyplinarności. Na dyplomie doktorskim można jako dyscyplinę napisać jedynie „nauki fizyczne”, co w niewielkim stopniu odpowiada tematyce pracy. 


\section{Dyscypliny horyzontalne i straty}

Warto podsumować straty, jakie ponosimy z powodu braku właściwego podejścia do interdyscyplinarności. W grudniu 1994 r. na konferencji w Tokio, kończącej 12 lat projektu komputerów piątej generacji, pojawili się bioinformatycy i biolodzy komputerowi. Po powrocie do Polski entuzjastycznie przedstawiłem propozycję rozwoju nowej dyscypliny na swojej uczelni, ale została publicznie wyśmiana informatyka $\mathrm{z}$ biologią? To wymaga 10 lat studiów, więc się nie przyjmie. Rektor nie chciał przedłużać zatrudnienia mojemu byłemu doktorantowi pracującemu w USA w life science jako bioinformatyk, argumentując, że u nas nie ma szans na habilitację, bo nie ma takiej dyscypliny. Dziesięć lat później pojęcie nauk o życiu rozpowszechniło się i powszechnie uznano bioinformatykę za ich fundament.

W tym samym 1994 r. zaproszono mnie do Albuquerque na konferencję o nauczaniu nauk obliczeniowych. Grant na 3 mln dolarów pozwolił na opracowanie podręcznika dla nowej, horyzontalnej dyscypliny. W 1997 r. napisałem 50-stronicowy rozdział w książce o naukach obliczeniowych, zatytułowanej Fascynujacy świat programów komputerowych. Kilkanaście lat później prof. Michał Kleiber na spotkaniu komisji informatyki PAN przyznał, że trzeba nauki obliczeniowe rozwijać (sam zajmował się takimi metodami), ale do tej pory nie udało się im nadać odrębnej tożsamości. Czy człowiek kończący studia medyczne jest w stanie pisać programy na superkomputery, by symulować złożone procesy biologiczne? Czy też może to zrobić informatyk, który zajmie się medycyną lub biologią molekularną i wszystkiego sam się nauczy? Jak możemy rozwijać takie specjalności jak medycyna cyfrowa (konferencje poświęcone tej tematyce gromadzą tysiące uczestników), jeśli nie mamy nauk obliczeniowych jako odrębnej, horyzontalnej dyscypliny? W 2014 r. powstała lista „,inteligentnych specjalizacji”, które zamierzamy w Polsce rozwijać w ramach współpracy europejskiej. Symulacje komputerowe znalazły się prawie we wszystkich 21 specjalizacjach. Proponowałem Radzie NCBR, by uwzględnić je jako osobny kierunek w Krajowym Programie Badań. Na spotkaniu Rady Interdyscyplinarnego Centrum Modelowania Matematycznego i Komputerowego (ICM UW) mieliśmy długą dyskusję nad tym, do jakiej dyscypliny zakwalifikować działalność wykorzystującą nasze superkomputerowe centra. Wydaliśmy na nie wiele miliardów i nadal wydajemy (w 2018 r. Polska przyłączyła się do inicjatywy budowy europejskiej infrastruktury superkomputerowej). Niestety oprócz małego programu studiów z inżynierii obliczeniowej, prowadzonego przez ICM, nie kształcimy specjalistów w tym zakresie, nie mamy też takiej dyscypliny badawczej. Kupiliśmy sobie wyczynowy samochód, ale brakuje kursów i uprawnień dla kierowców.

W Moskwie i w Abu Zabi powołano w 2020 r. uniwersytety zajmujące się sztuczną inteligencją. To kolejna horyzontalna dyscyplina, z której można zrobić duży uży tek, jeśli tylko potrafi się połączyć wiedzę dotyczącą informatyki z okreś- 
loną domeną zastosowań. Przez ostatnie dwa lata kraje Unii Europejskiej utworzyły liczne instytucje zajmujące się rozwojem i wykorzystaniem sztucznej inteligencji. W Polsce wiele się na ten temat mówiło, ale przez dwa lata nic nie zrobiono. Mamy wiele innych dyscyplin, które trudno jest rozwijać. Kognitywistyka, historia nauk medycznych, pedagogika w różnych naukach, studia miejskie, badanie procesów zrównoważonego rozwoju (sustainability studies) to tematy poruszane w zespole transdyscyplinarnym, jaki utworzyłem na internetowym forum Ministerstwa Nauki. Podawałem przykład Nagrody Nobla dla małżeństwa Moserów z Norwegii za odkrycie komórek miejsca. Ich badania zaliczane są do komputerowych neuronauk kognitywnych. To dla nas dyscypliny w trzech dziedzinach: informatyki technicznej w dziedzinie nauk inżynieryjno-technicznych, kognitywistyki w dziedzinie nauk o komunikacji społecznej i mediach oraz neuronauk, o których nie wiadomo, czy są w naukach medycznych czy biologicznych. W Polsce neurokognitywistyka jest oceniana jako specjalność wspólnie z dziennikarstwem, bibliologią i informatologią w obrębie jednej dyscypliny. Można ją też wrzucić do worka z setkami specjalności medycznych, od stomatologii do radiologii i medycyny komputerowej.

\section{Punktoza i sterowanie nauką}

W Pauzie Akademickiej napisałem o wpływie punktacji czasopism na rozwój nauki („Naukowa ślepota” w nr 435 z 6.09.2018 r.). Niestety, punkty decydują o kierunkach polityki naukowej, ale najpierw należało zdefiniować politykę, określić priorytety, a potem przyznawać punkty tak, by ją realizować. Mamy teraz oficjalną listę ośmiu dziedzin i 47 dyscyplin naukowych, ustaloną rozporządzaniem z 1.10.2018 r. Ta klasyfikacja dziedzin i dyscyplin nauki w dużym stopniu determinuje możliwość zdobywania grantów badawczych i określa możliwości prowadzenia prac doktorskich. Nie pomaga nam to w zwiększeniu udziału w projektach międzynarodowych. W krajach Europy Zachodniej i USA jest znacznie większa swoboda w określaniu dziedzin/dyscyplin, z których można zrobić doktorat. Szczególnie w Wielkiej Brytanii i Stanach Zjednoczonych uczelnie same mogą określać dziedziny/dyscypliny nauki, w jakiej stopień doktora jest nadawany.

Rozwiązywanie rzeczywistych problemów o dużym znaczeniu społecznym często wymaga współpracy międzyobszarowej. W Polsce badania tego typu zawsze były na marginesie i raczej nie zanosi się na zmiany. Ze względu na ciągle rosnącą liczbę dyscyplin i specjalności naukowych proponowaliśmy (m.in. jako Polskie Towarzystwo Kognitywistyczne) uwzględnienie badań międzyobszarowych jako osobnego obszaru, w ramach których uczelnie spełniające odpowiednie kryteria mogłyby same definiować dziedziny i dyscypliny określające charak- 
ter prowadzonych badań, wpisując je na dyplomach doktorskich i habilitacyjnych. Niestety to się nie udało i w obecnej sytuacji są nawet wątpliwości, czy na dyplomie doktorskim można wpisać specjalność naukową, gdyż ustawa tego nie przewiduje. Jeśli na dyplomie jako dyscyplinę wypiszemy np. „nauki o komunikacji społecznej i mediach", to nie wiadomo, czego on dotyczy. Czy jest to medioznawstwo, dziennikarstwo, bibliologia, informatologia? Może chodzi o kognitywistykę, która ma wiele odmian, w tym badania z użyciem neuroobrazowania, EEG, neuromodulacji z wykorzystaniem przezczaszkowej stymulacji magnetycznej czy innych wyrafinowanych metod eksperymentalnych? Niestety nie mamy takiej dyscypliny jak neuronauki, a trudno zaliczyć neuroobrazowanie do medycyny ogólnej. Brytyjczycy mają łatwo, my nie wiemy, gdzie się ze swoimi badaniami przypisać teoretycznie do wielu dyscyplin, ale w praktyce oznacza to całkowite rozproszenie środowiska naukowego i utrudnienia w zbudowaniu tożsamości ekspertów z danej specjalności. Punkty ministerialne miały ograniczyć tyranię bibliometrii, ale dobre chęci skończyły się jeszcze gorszą punktozą. Czy stosunkowo mała liczba szerokich dyscyplin pomaga interdyscyplinarności? Różne specjalizacje pomieszane są w obrębie jednej dyscypliny, gdzie nie da się zastosować wspólnych kryteriów oceny, a bliskie sobie specjalności znalazły się w odrębnych dyscyplinach. Część nigdzie nie pasuje. Handel punktami będzie się rozwijał. System oceny nauki zniechęca do współpracy, wymuszając podziały przez przypisanie się do maksymalnie dwóch dyscyplin na kilka najbliższych lat.

Profesor Jerzy Szwed (UJ, były wiceminister nauki) napisał o NCN:

Jednak w procedurach konkursowych pominięto bardzo istotny krok, stosowany przez ERC (European Research Council). Tam - w przypadkach, gdy projekty nie mieszczą się nawet $\mathrm{w}$ tych szerokich panelach - dochodzi - ponad panelami - do dodatkowej rundy, rundy prawdziwie interdyscyplinarnej. [...] w przypadku interdyscyplinarności zdaję sobie sprawę, że łatwo można ją ośmieszyć wybranymi przykładami. Ale jestem też pewien, że jej niewidzialna ręka jest kluczowym narzędziem we frontowych badaniach naukowych i w nowoczesnym nauczaniu (Pauza Akademicka nr 303 z 2015).

Wszyscy o tym wiedzą, ale przepisów nie układają ludzie, którzy sami mają jakieś pojęcie o interdyscyplinarnej nauce. Dlatego warto podkreślać, jak przepisy nas w Polsce krępują.

\section{Jak można sensownie sterować rozwojem nauki?}

Biuro polityki naukowej Narodowego Instytutu Zdrowia (NIH Office of Science Policy, USA, https://osp.od.nih.gov/) publikuje coroczne raporty na temat obiecują- 
cych nowych specjalności naukowych. Neuroparazytologia, nutrigenomika, neurodynamika kognitywna, neuroekonomia, kliodynamika, komputerowe nauki społeczne i niezliczone biomedyczne specjalności są aktywnie wspierane, bo dają nadzieję na ważne odkrycia. Naukowcy nie muszą się martwić tym, że ich publikacje będą wydawane w nowo powstałych czasopismach specjalistycznych o bardziej dopasowanym do ich pracy profilu, a nie w periodykach wysoko punktowanych, o wysokim współczynniku wpływu. Oczywiście wymaga to oceny jakości publikacji, ale nikomu nie przyjdzie do głowy, by oceniać nowe czasopisma (zwłaszcza w nowo powstających specjalnościach) na podstawie wskaźników bibliometrycznych. Szczególnie nowy wskaźnik zalecany przez MNiSW, czyli Field-Weighted Impact Factor (FWIF), jest bardzo szkodliwy, bo wagi czasopisma względem innych w szerokich dyscyplinach nie da się dobrze wyznaczyć. Uwzględnianie tylko kilku ostatnich lat w cytowaniach nie pozwala ocenić wpływu wielu przełomowych prac, które stają się ważne w dłuższym okresie. W ten sposób zmarnujemy to, co najcenniejsze. Wielu noblistów miało na pewno niski FWIF przez całe lata, zanim ich doceniono. Deklaracja z San Francisco w sprawie oceny nauki z 2012 r. (DORA) podkreśla, że wskaźniki bibliometryczne nie służą ocenie pojedynczych publikacji ani naukowców. Słynny indeks wpływu, impact factor (IF), czasopism został wprowadzony dla bibliotekarzy, by ułatwić im wybór czasopism do subskrypcji, a nie oceniać naukowców i jakość nauki w niewielkiej liczbie dyscyplin.

W czasopismach Journal of Informetrics i w Scientometrics jest wiele publikacji pokazujących, jak skalowanie cytowań i procedury normalizacyjne powinny wyglądać. Wymaga to uwzględnienia tysięcy specjalności, a nie tylko kilkudziesięciu dyscyplin. Wystarczy opracować listę wszystkich specjalności, wykorzystując klasyfikacje biblioteczne lub Wikipedię, zidentyfikować najważniejszych naukowców w każdej z tych specjalności i poprosić, by zrobili ranking najważniejszych czasopism ze swojego punktu widzenia. Narzędzia informatyczne pozwalające na taką operację nie są aż tak skomplikowane, można więc uwzględnić ponad tysiąc specjalności. Warto używać punktów, ale powinny one w pełni odzwierciedlać specyfikę danej specjalności. Taki ranking częściowo powinien pokrywać się $\mathrm{z}$ ocenami bibliometrycznymi, ale dałby szanse na przypisanie odpowiedniej rangi ważnym czasopismom i konferencjom w nowych oraz niszowych specjalnościach. W szczególności słabo cytowane badania w różnych specjalnościach społeczno-humanistycznych mogłyby zostać odpowiednio docenione. Odrębnym zagadnieniem jest fatalna ocena konferencji naukowych w informatyce, którym również przyznano punkty. Obecna ocena oparta jest na liście rankingowej CORE, powstałej na podstawie sugestii australijskich naukowców. Wiele konferencji organizowanych od kilku dekad w Polsce nie dostało żadnych punktów, bo nie zapraszało australijskich uczonych, więc o nich zapomniano. Jak można było dopuścić do takiego niszczenia nauki polskiej, narzucając nam nieprzemyślany system oceny jakości konferencji i czasopism? Dlaczego polscy naukowcy nie zostali zapytani, 
które konferencje uważają za ważne w swojej specjalności? Czyżbyśmy mieli takie wielkie zaufanie do Australijczyków?

Oceny czasopism, klasyfikacja dyscyplin, rady doskonałości, konkurs na uczelnie badawcze i wiele innych nowych rozwiązań ustawy 2.0 wyrządzi nauce polskiej poważne szkody, których można było uniknąć. Napisałem o tym w kilku artykułach w Pauzie Akademickiej i kilku innych publikacjach, dostępnych tutaj: http://www.is.umk.pl/ duch/cv/WD-topics.html\#science. 
